\title{
“Oh, I have a story": narrative as a teacher's classroom model
}

\author{
Kathleen Jeanette Martin \\ University of California, Santa Barbara, Graduate School of Education, CA 93106, USA
}

\begin{abstract}
This paper examines the teaching practices of one American Indian teacher in a high school literature class. It explores the teacher's use of narrative as an instructional strategy designed to convey abstract concepts through concrete experience. The narratives engage students in critical thinking and personal reflection, and provide them with the opportunity to make connections between social and historical contexts. In addition, the teacher uses stories to contrast multiple contexts with personal experiences, which reflects teaching strategies previously identified as those used by effective teachers. There is evidence that sharing ideas and concepts through story is an important way of encouraging social relations and helping students make connections between what they are learning in school and what they know of the world. Based on data analysis, this study presents a model of the teacher's use of narrative as a strategy to pose critical questions, frame a context for discussion, encourage students to reflect on personal perspectives, and introduce ideas and concepts. The model provides a visual representation of the teacher's use of narrative as a way of clarifying course content, contextualizing meaning, and reinforcing understanding.
\end{abstract}

Keywords: Teaching strategy; Narrative, Native American classroom

\section{Introduction}

The relationships among cultural traditions, social contexts and environments, and "what makes us want to learn, with whom, and on what basis are all facets" (Eckermann, 1994, p. 27) of classroom communities. "Teachers, like the students, bring understandings, concepts, explanations, and interpretations to the classroom that result from their experiences in their homes, families, and commun- ity cultures" (Banks, 1993, p. 12). Yet, this form of "connected discourse occurs so rarely...[and] even in more effective classrooms teachers do little that meets any acceptable image of serious interactive teaching" (Gallimore \& Tharp, 1990, p. 175). Many theorists have presented discussions of empowering education, democratic education, and critical pedagogy (Banks, 1993; McLaren, 1995; Shor, 1993) that are useful perspectives for identifying ideas, categories, and the construction of teaching practices in general. Yet, focused research efforts in classroom contexts are needed to find ways that "embrace and enhance the talents of those who have long struggled for voice and educational opportunity" (Darling-Hammond, 1997, p. 30).

Through the mutual sharing of stories and the construction of a social self within the classroom 
students and teachers can be motivated to explore alternative interpretations to classroom material and experience (Bruner, 1996). Stories can provide "the intermingling of voices and exploring of story possibilities. . .[so that students] feel like masters of their thinking" (Freire, 1996, p. 199). "In sharing stories, we have the potential for forging new relationships...[in] local classroom cultures in which individuals are interconnected and new we's are formed" (Dyson \& Genishi, 1994, p. 5). In fact, it is not only important, but necessary for teachers and students to construct meaning and share knowledge through teaching and learning interactions and communication between members of the group (Gallimore and Tharp, 1990; Santa Barbara Discourse Group, 1998). Exploring beliefs in classrooms through "story as a means of constructing and evaluating ourselves, others, and experience" (Dyson \& Genishi, 1994, p. 238) may contribute to a better understanding of these issues. A critical question then is how and by what means can teachers and students work toward a mutual understanding and sharing of knowledge within classroom communities?

Typically in schools, classroom communities emphasize individualistic or independent development, which is the dominant perspective of education in the United States. However, many students come from communities where interdependent development is more heavily valued (Delgado-Gaitán and Trueba, 1991; Greenfield and Cocking, 1994; Nieto, 1996). Communities that are characterized as interdependent value "serving others through benevolence, sharing, and caring", while those characterized as independent are "grounded in self-protection and individual rights" (Greenfield and Cocking, 1994, p. 7). Many American Indian communities value and support the interdependent development model. Interestingly, in other schoolrelated research, relationships that value respect and caring as vital components of the social construction of knowledge are central to feelings of belonging and affiliation (Darling-Hammond, 1997; Freire, 1996; Witherall \& Noddings, 1991). Schooling experiences that account for success include cultural explanations "of what people do (their interaction patterns) but also explanations based on their personal and collective histories for why they choose to act in certain ways (their beliefs)" (McAlpine, Eriks-Brophy \& Crago, 1996, p. 390). Thus, successful schooling experiences incorporate interaction patterns that reflect community life and are supportive of community beliefs.

\section{Focus of paper}

The focus of this paper is on a Lakota (Sioux) teacher's high school literature class and her use of story for constructing a classroom community that is congruent with community beliefs. Finding ways to make the processes and differences explicit and accessible to teachers as a way to "build a theory of education and teaching" (Gallimore \& Tharp, 1990, p. 175) was also an important focus. The research questions that guide this study are:(1) In what ways does the teacher use storytelling and narrative to contribute to the construction of a classroom community? (2) What teaching practices does the teacher use to create a learning community that provides students with the necessary preparation for college and the ability to think critically? (3) Does the teacher use teaching practices and strategies that can contribute a useful model for other teachers? The following section provides the theoretical framework that guides this study based on social interaction theory and narrative research.

\section{Theoretical framework}

The notion that social interaction is an underlying evolutionary source of human intelligence and that relationships between individuals support higher mental functions has been a topic of research for a number of years (Cole, 1996; Cole, JohnSteiner, Scribner \& Souberman, 1978; Freire, 1996; Goody, 1996). Vygotsky's effort in "charting developmental changes is, in part, to show the psychological implications of the fact that humans are active, vigorous participants in their own existence and that at each stage of development children acquire the means by which they can competently affect their world and themselves" (John-Steiner \& Souberman, 1978, p. 123). Vygotsky's theory 
asserts that the "intellectual skills children acquire are directly related to how they interact with others in specific problem-solving environments" (Moll, 1990, p. 11). This implies the notion that education is not only central to cognitive development, but is the ultimate sociocultural activity (Moll, 1990). In this perspective, "literacy learning takes place in a social environment through interactional exchanges in which what is learnt is to some extent a joint construction of teacher and student" (Cook-Gumperz, 1986, p. 8). Moll and Greenberg (1990) note that "social relations of exchange" are reciprocal, and they establish a mutual exchange process that works toward maintaining trust among participants (p. 344). In this perspective, classrooms are multi-layered environments that deal in processes and dynamic social relationships (John-Steiner, Panofsky \& Smith, 1994) that are embedded in the teaching and learning process. These environments "contain considerable complexity" (Scollon \& Scollon, 1981, p. 5).

Stories are well-suited to explicating this complex world of social interaction as well as encouraging and contributing to a respect for the thoughts, feelings, and interests of others (Beck, Walters \& Francisco, 1942; Joe, 1994). Narrative invites attention since it is the "most pleasurable form that language, spoken or written, takes, [and] its content is not ideology but action, and those situations which action creates" (Havelock, 1986, p. 75). In classrooms, a teacher's use of narratives, humor, and self-disclosure has been found to be an effective tool in helping students to understand the material (Downs, Javidi \& Nussbaum, 1988). This lends support to the findings of Holladay (1984) that suggest effective teachers engage in narrative activity more often than less effective teachers. However, "within American education there is a wide spread bias against the use of narrative as a communicative medium" (Scollon \& Scollon, 1981, p. 6).

Narrative is characterized as "a mode of thinking, a structure for organizing our knowledge, and a process for the vehicle of education" (Bruner, 1996, p. 119). Through the use of stories multiple definitions and interpretations of situations are possible, and cultural philosophy and viewpoint are embedded and vital to an understanding of the narrative. Heath (1986) maintains that "narrative forms bring to consciousness past or imagined experience and require gestalt-level processes of linking similarities and dissimilarities across space and time" (p. 88). "It is the very context dependence of narrative accounts that permits cultural negotiation which, when successful, makes possible such coherence and interdependence as a culture can achieve" (Bruner, 1991, p. 18). Most importantly, narratives provide sources of cultural expression and mind, not a record of the world, but rather a creation "according to its own mix of cultural and individual expectations" (Chafe, 1990, p. 81). This strengthens relationships and connections with others and establishes each individual's place within the context of generational relations.

Interdependent relationships among individuals form a fundamental component of many American Indian communities (Cajete, 1994; DelgadoGaitán, 1987; Hymes, 1981; Ong, 1982; Swann, 1994), and storytelling is the principal means of connecting with others. Stories are "like a gaff hook reaching out over a distance and becoming one with another person who is hooked" (Dauenhauer \& Dauenhauer, 1990, p. ix). It is a way of connecting with others through feeling or affect, a personal way of engaging someone in process (Chafe, 1990). One of the reasons for studying oral traditions is that "orality entails a set of powerful and effective mental strategies, some of which. . have been attenuated and undervalued in many aspects of our Western cultures and educational systems" (Egan, 1987, p. 448). Interdependent communal cultures use narrative as a way of conveying expectations and encouraging others in relationships. Furthermore, the use of orality as a crucial form of communication is not a deficit mode in comparison with the so-called literate traditions (Goody, 1987; Ong, 1982). In fact, "we need to see orality as an energetic and distinct set of ways of learning and communicating, not simply as an incomplete and imperfect use of mind awaiting the invention of literacy" (Egan, 1987, p. 454).

Previous studies have identified the use of stories and narratives as significant features and aspects of American Indian classrooms (Erickson \& Mohatt, 1982; Greenfield \& Cocking, 1994; Philips, 1983; Scollon \& Scollon, 1981; Tharp \& Gallimore, 1988). In general, American Indian communities 
encourage individuals to reflect on personal experience, contribute through self-disclosure when appropriate, and use narrative to relate personal "story" as a way of increasing dialogue and interaction with others (Braid, 1996; Chafe, 1990; Egan, 1987; Heath, 1982). "Knowledge must be passed on in such a way that it maximizes relevance to the learner and minimizes the threat to individual autonomy and flexibility" (Scollon \& Scollon, 1981, p. 105). As Scollon and Scollon (1981) note, "Athabascan oral narrative constitutes an art of the highest development. . and they have invested the best of their artistic energies in the education of children [and] the management of their social relations" (p. 6). In general, "the circumstances that prompt a particular telling are as much a part of the story's significance as the details of the plot" (Jayner, 1994, p. 424). This study explores a Lakota teacher's use of narrative for establishing connections between herself and students, fostering a shared interpretation of the world, and shaping a classroom community.

\section{Method}

\subsection{Case study design}

A case study design was used in order to investigate "a contemporary phenomena within its real-life context" (Yin, 1994, p. 13), and it is a methodological approach that provides the opportunity to look closely at phenomena. It "involve[s] systematically gathering enough information about a particular person, social setting, event, or group to permit the researcher to effectively understand how [they] operate or function" (Berg, 1998, p. 212). The purpose for this study was to look closely at a particular trait or characteristic, and provide an exemplary profile of one teacher's practices. This is termed "intrinsic case study" (Berg, 1998; Stake, 1995) since it illustrates a particular characteristic, issue or problem. The intent of an intrinsic case study is "not to understand or test abstract theory or to develop new theoretical explanations; instead, the intention is to better understand intrinsic aspects of the particular [case]" (Berg, 1998, p. 216). This is "inten- sity-sampling" where the purpose is to select an information-rich case for in-depth study (Patton, 1990 , p. 182). It is not meant to be a study of an ideal cultural type or a way of interacting in American Indian classrooms (Erickson \& Mohatt, 1982), but a particular case that can illuminate phenomena not previously explored or understood.

\subsection{Personal context}

This study is based on data originally gathered for dissertation research, and the author is a researcher and faculty member in a university setting. This research began from an interest in the ways communities foster collaborative and interdependent relationships. I discovered that many Indigenous communities support participative social interaction, and I became interested in knowing more about American Indian Nations in the midwest United States. I began my fieldwork in 1994 with an initial visit to South Dakota, and established relationships with the local school district and teachers so that I might observe and participate in classes at the beginning of the 1995 and 1996 school years.

Writing as a non-Indian, I have tried to be aware of my philosophical perspectives, and use reflection to gain understanding and awareness of personal beliefs and biases. I have made every attempt not to romanticize nor patronize the participants in this study, and to be conscious of the power relations inherent in this type of research. I hope to present the teaching practices of one teacher who uses narrative to create a learning context, provide opportunities that encourage critical thinking, and present material in a way that engages students through story.

\subsection{High school context}

The high school in which this research was conducted is on one of the six Lakota reservations in South Dakota, and has approximately 300 students with classes of between 6 and 20 students. The school district and curriculum is supervised by the state of South Dakota and the tribal government, and the majority of teachers at the high school are non-Indian. 
In the original study, 12 high school classrooms of six American Indian and six non-Indian teachers were observed. All of the teachers have a South Dakota teaching credential, and were chosen based on their teaching experience and the grade level(s) they teach. The data indicate use of narrative is a prevalent teaching strategy in the Lakota teachers' classrooms. For purposes of this paper, one of the Lakota teachers stands out as exemplary, and is an example of an "intrinsic case" in which it is possible to make a point "important in the scheme of things" (Patton, 1990, p. 174).

\subsection{Data sources and collection}

For this paper data were gathered from the teacher's junior and senior advanced placement literature classes over a period of four weeks during the beginning of the 1995-1996 and 1996-1997 school years. Class periods were $55 \mathrm{~min}$ in length and a variety of data were gathered through participant observation, interviews, and extant data sources. Participant observation in classes provided the opportunity for interaction and informal conversations on teaching practice with the teacher. As with many American Indian communities where recorded information has been misused and is no longer allowed, video and audio tape recording of the classes were not permitted. Field notes were taken during class times and transcribed that same day. This provided focused concentration on the interaction, dialogue, and actions of participants, while simultaneously limiting the amount of possible interpretation in the setting.

During each of the two years, two semistructured interviews of approximately 45-60 min in length were conducted with the teacher. As with the classes, tape recording of the interviews were not permitted. Notes were taken during the interviews, and the statements were read back to the teacher for clarification and accuracy. All class materials were read by the researcher and reviewed prior to class discussions.

\subsection{Data analysis}

Multiple approaches to data analysis were utilized in order to provide a range of descriptions.
A "grounded theory" approach was used (Glaser \& Strauss, 1967) to identify categories and exhibit patterns. In conjunction with this approach, data were analyzed using "three concurrent flows of activity: data reduction, data display, and conclusion drawing/verification" (Miles \& Huberman, 1994, p. 10). The observation and interview data from the teacher's class which is the focus of this paper were coded and tabulated, and charts and data displays were organized. This provided the opportunity to describe and identify the teacher's perspectives, methods of instruction, and teaching strategies. In addition, quotations from the teacher's interviews, class lectures, narratives and interactions with students were "selected to capture the context and support conclusions so that readers might judge the transferability of the meaning and the interpretation of the data" (Collinson, 1993, p. 75).

\section{Findings}

Theresa Morrow (pseudonym) teaches advanced placement literature in the ninth through twelfth grades, and she has been teaching in the high school for 12 years. She began her career 13 years ago, and has a bachelor's degree and teaching credential from a South Dakota university. She is of Lakota heritage, was raised in the community, and her family still resides in the area. She has a working knowledge of Lakota language, and is supportive of cultural traditions. During an interview she says, "I have moved quite often and lived on and off the reservation", and she finds it a blessing that for the past 12 years her children have been able to grow up with the same friends. She says, "I can't imagine that. I have seen their friends grow up".

\subsection{Philosophy of teaching}

In the initial interview, Theresa describes her philosophy of teaching as predominately Western in nature, and grounded in the subject and something that you want to know more about. She says, "I love to read. [You have to] love your subject - love what you are doing. [It] teaches students respect for what you are doing and shows you have respect and believe it's important". 
Theresa's lessons routinely contain a variety of physical, cognitive and affective strategies that help to explicate the text. She considers concrete experiences, feelings, and students' reflections regarding the material as significant aspects of learning, and they are routinely part of the discussion.

During the interview she describes how she accomplishes this by saying:

For instance, when I teach transcendentalism and we are reading Ralph Waldo Emerson, you have to know what it means to have everything in its place. [Everything] has form and order. You have to understand where Emerson was coming from. I use this example with my students. First I say, "OK guys, are all of you feeling all right.? Yes. Are you sure? Yes. Well, just swallow and see if everything is OK". They swallow and yes it's OK. Then I tell them to hold their hand up to their face and spit in their hand, most of them go "YUK", but a few of them do it before I say anything else. So then I tell them to lick it back up and they go "YUK", but I ask them what is the difference? A few minutes ago you just swallowed it. Now, it's out of place. That's transcendentalism.

In addition, she believes helping students understand the historical, political, and cultural context of what they are reading and discussing is critical to furthering their ability to interpret and understand the material.

\subsection{Classroom context}

There are 12 students in Theresa's senior literature class, and she uses a variety of instructional strategies from direct instruction to collaborative groups. She says, "I give them worksheets [with discussion questions] and tell them to work in pairs. I know they are difficult, but I want students to work hard and get it themselves". During lectures, she repeats sentences for emphasis, and indicates important points for note-taking. She defines new or difficult vocabulary words and waits for students to write down the definitions. Theresa views this as important for preparing students for college work, and on several occasions she leaves the room to go to the library to look up additional material. During one class she says, "Maybe you'll get really motivated about this and go to the library to look things up". She hopes her example will generate the same interest in learning that she has, and she conveys this expectation to her students.

In a discussion of a Louise Erdrich short story, Theresa asks questions that require students to draw conclusions, examine perspectives, and thoughtfully reflect on the situation in the story. She has developed a list of more than 20 questions for discussion such as:

Why does the law not recognize individuals as competent until age 18 ?

Is 18 too young? too old? Who decides who is too old or too young?

What will Buddy lose if he goes to a non-Indian home?

Does that mean that non-Indians should never be allowed to take Indian children?

What are the problems with outside intervention into family conflict? the advantages?

During the interview, Theresa says the students almost never complete all of the questions since they become so interested in the different aspects, opinions, issues, and concerns that the questions generate.

Through an analysis of the data, Theresa's classroom narratives can be divided into two categories: personal and cultural. The personal narratives reflect stories of her experiences and feelings or share her perspectives and ideas. The cultural narratives present elements of Lakota values, cultural beliefs, or traditions. Both categories use historical contexts to discuss current events, student issues, and personal perspectives. Table 1 presents an overview of the personal and cultural narratives and indicates how Theresa uses them in her teaching to create a context, self-disclose, question and clarify class material, and state her expectations of students.

\subsection{Personal narratives}

In the "exchange student" narrative, Theresa shares an awareness of her own lack of sensitivity, 
Table 1

The teacher's personal and cultural narratives in the high school class for creating a context, self-disclosing, questioning and clarifing content, and stating her expectations

\begin{tabular}{|c|c|c|c|c|}
\hline & Creates context & Self-discloses & Questions and clarifies & States expectations \\
\hline \multicolumn{5}{|l|}{ Personal narratives } \\
\hline "Exchange Student" & $\begin{array}{l}\text { Discusses inappropriate } \\
\text { behaviors }\end{array}$ & $\begin{array}{l}\text { Discloses personal bias } \\
\text { and perspective }\end{array}$ & $\begin{array}{l}\text { Uses an example of } \\
\text { studying something new } \\
\text { or unfamiliar }\end{array}$ & $\begin{array}{l}\text { Implicitly states to } \\
\text { students, try not to do this }\end{array}$ \\
\hline "Catholic Church" & $\begin{array}{l}\text { Reference to the historical } \\
\text { context of the church }\end{array}$ & $\begin{array}{l}\text { Relates her experience and } \\
\text { impressions of the Church }\end{array}$ & $\begin{array}{l}\text { Asks students to "imagine } \\
\text { what that was like?" }\end{array}$ & $\begin{array}{l}\text { Alerts students to future } \\
\text { material }\end{array}$ \\
\hline "Canterbury Tales" & $\begin{array}{l}\text { Makes connection to Ben } \\
\text { Franklin quotation. } \\
\text { Discusses the Doctor }\end{array}$ & $\begin{array}{l}\text { Tells students about her } \\
\text { illness, clinic experience, } \\
\text { and recovery }\end{array}$ & $\begin{array}{l}\text { Makes an analogy to the } \\
\text { text to clarify }\end{array}$ & $\begin{array}{l}\text { Allows for differences in } \\
\text { student versus teacher } \\
\text { understanding }\end{array}$ \\
\hline \multicolumn{5}{|l|}{ Cultural narratives } \\
\hline $\begin{array}{l}\text { "Medieval } \\
\text { Literature", }\end{array}$ & $\begin{array}{l}\text { Discusses values in past } \\
\text { and present }\end{array}$ & $\begin{array}{l}\text { Shares that the value of } \\
\text { loyalty is important to her }\end{array}$ & $\begin{array}{l}\text { Encourages students to } \\
\text { think of values and } \\
\text { applications }\end{array}$ & $\begin{array}{l}\text { States what she would do } \\
\text { and students can use her } \\
\text { ideas }\end{array}$ \\
\hline $\begin{array}{l}\text { "Get up and Bar the } \\
\text { Door" }\end{array}$ & $\begin{array}{l}\text { Frames story in } \\
\text { contemporary language, } \\
\text { draws analogy to student } \\
\text { relationships }\end{array}$ & $\begin{array}{l}\text { Shares her knowledge of } \\
\text { older couples and how } \\
\text { they behave toward one } \\
\text { another }\end{array}$ & $\begin{array}{l}\text { Asks students to reflect } \\
\text { about the older couples } \\
\text { they know }\end{array}$ & $\begin{array}{l}\text { Expects participation. } \\
\text { Implies she understands } \\
\text { the difficulties of } \\
\text { relationships }\end{array}$ \\
\hline "John Smith" & $\begin{array}{l}\text { Discusses context of } \\
\text { Virginia society in } 1607 \text {, } \\
\text { people's values, and } \\
\text { incongruities }\end{array}$ & $\begin{array}{l}\text { Shares what she thinks } \\
\text { and that she can argue } \\
\text { either way }\end{array}$ & $\begin{array}{l}\text { Questions students on } \\
\text { their perspectives, beliefs, } \\
\text { ideas, and values }\end{array}$ & $\begin{array}{l}\text { Students have their own } \\
\text { opinions and can express } \\
\text { them }\end{array}$ \\
\hline
\end{tabular}

and emphasizes appropriate behavior while relating it to the students' experience in their Lakota language class. She says to her students,

Do you guys remember Reuben our exchange student [from Spain]? OK...He would listen to the Spanish students and say they sounded like a "retarded Spaniard" because their pronunciation and grammar were poor. But I found myself doing what I ridicule other people for doing. So I would say [to him], 'BREAKFAST?' [really loud] like he couldn't hear instead of speak English.

She compares this context to the students' personal experience by saying, "Now any of you guys in Lakota, how are you learning that?...Well, to a Native speaker you probably would sound funny". Theresa emphasizes the importance of perspective and context, and an awareness of personal beliefs.
The "Catholic Church" is the basis for the second narrative, and the class is discussing a piece of literature from the 17th century. Theresa believes understanding historical context is important, and she contrasts her personal experience of the Church with the context of that century. She says:

Why is [the Church] important to people? Because it provided common elements of culture. The thing about it was, it was the same from one side of the country to the other. I want you to put this in your notes. [The] Church was an extremely powerful force. Church crossed physical, cultural, language barriers. Latin was known or used everywhere the Church was. When I was a young girl, and I'm old enough to remember it being in Latin, I remember Church was mysterious when I was growing up. The priest and the alter boys faced away from you. You didn't know what they were doing - bells ringing-incense burning-candles burning-solemn and quiet 
- and they used to do high mass which was all sung. . .Imagine what it must have been? [The] Latin of the Church indicated an educated person. Church was the seat of power for the masses and the masses responded to it...We're going to be reading someone named Chaucer - lived around 1100 . Some of his characters were about the Church and he didn't portray them too well.

Ms. Morrow connects the material to the social context of the time period by saying, Latin was known by educated people, and the Church was the most powerful, constant and unifying force across cultures. She uses her personal experience with the Catholic Church as an example of how it must have felt during that time to be an uneducated person, watching a ceremony where the participants faced away from you, and spoke in a language you did not understand. She then introduces future class material that relates to the topic.

The third personal narrative takes place during a reading from the Canterbury Tales. The Tale they are reading describes how the Doctor takes credit for healing people when God is more likely to be responsible for the healing. Ms. Morrow says, "OK let's have some fun with it. .Oh, I have a story". The students make faces and there is a slight groan. She says, "You know how I am with my stories".

[Do you] remember this aphorism from Ben Franklin: "God heals and the doctor takes the fee". So remember when my throat was sore, well after about a week I decided to look in my own throat with a flashlight and I saw some white stuff on one of my tonsils. Well, I went to the clinic and it was really busy. So I left and I could have come back and gone to the emergency, but I didn't feel right about that. So I thought I would wait until the next day, and then, I just got better anyway. So now after we [read about] the Doctor [in the Canterbury Tales] make some inferences about the time. It's easy for me to make inferences about the Doctor because I have a history [with doctors]. So I wouldn't expect the same of you.

Theresa connects the topic of doctors to previously discussed material, the aphorism by Ben
Franklin, and transitions to her recent sore throat and experience at the Indian Health Clinic (IHC). Students are aware the IHC is routinely busy, and Theresa states her feelings about not going to the emergency room when her sore throat does not seem to be serious enough to be classified as an emergency. She relates her experience by saying, then "I just got better anyway", implying God healed me without the doctor's interference. Finally, she tells students to make some interpretations about the text, and expresses her expectations of them based on their existing knowledge.

\subsection{Cultural narratives}

The following three narratives from Theresa's class draw on cultural ideals, historical material, and current events. During discussions, she encourages students to think about any relevance the readings might have for them. The first narrative describes bravery, loyalty, and justice in "Medieval Literature", and she tells students:

Stop and think, what is the message and then ask yourself, is that relevant at all in 1996? Let me help you out with one. You have a hero who comes along and saves people and slays dragons. Is that relevant or irrelevant? People remember, go a little bit deeper than just the words in the poem. What this represents is the triumph of good over evil...loyalty has its own rewards [like being] loyal to people - always on their side through thick and thin. You guys think about it. Is that relevant today? It's OK if you think they're irrelevant as long as you tell me why. [A student asks if they can use her examples.] Yes, I would take the loyalty one because that could be really interesting.

In the second cultural narrative, "Get up and Bar the Door", students are encouraged to connect the poem they are reading to their own relationships. The poem is about a husband and wife who are fighting, and neither person wants to get up and lock the door. The class reads aloud, "if it stays open 100 years it's not going to be shut by me". Theresa interrupts to say: 
They are at a stand off. . Now remember guys, this is a time when people fear for their safety. The door is still open and 2 men come into the house, neither the husband or wife are speaking. So the men eat the pudding the wife is making, and these guys are talking about doing the couple some harm, so the husband speaks first. You know guys, when relationships start out you can't do enough for the other person - rub their back - get coffee - after about a year the individual personality surfaces and you begin to assert yourself. This is how this couple is with each other. They are like some older couples I know, grandparents and older couples. You guys know some people like that.

Theresa begins the discussion by alluding to the couple's dangerous situation, and draws on the students' knowledge of relationships in two ways. First, she alludes to the social relationships of teenagers in general, and then contrasts this with the relationships of grandparents and older couples in the community. This is an important cultural aspect of American Indian communities that is readily understandable to students.

In the "John Smith" narrative, unlike the other examples, Theresa intersperses the text with personal perspectives. She begins with a social history of the Puritan ethic of Virginia in 1607 and a definition of bias as "partiality or inclination toward a certain position". The writings of John Smith are a South Dakota curriculum requirement, and during one interview Theresa says that she would probably not use it if it was not required. Her discussions are designed to help students understand the Puritan ethic of the time that disregarded Native American ethics and philosophy. Table 2 presents the teacher's narrative, a synthesis of the text, the juxtaposition of ethics and values, and the teaching strategies she uses to explicate the material.

Theresa uses multiple representations of content, perspective-taking, and critical literacy for engaging students in discussion. Based on analysis of the data presented in Table 2, Theresa initiates a discussion of the John Smith narrative by selfdisclosing her perspective of the material. In lines 2 , $5,8,10$, she transitions to the abstract ideas of
Puritan and English philosophy and ethics. In lines $4,7,9$, and 10 she poses critical questions that frame the context of the discussion, and she encourages students to reflect on the material from multiple perspectives. She then asks students to reflect on their personal perspectives using their own concrete experiences to make the material more relevant. She enlarges the discussion to American Indian philosophy and the misconceptions about Indian peoples, and she concludes the discussion by introducing additional ideas and concepts and restating her opinions. Ms. Morrow uses the narrative to skillfully move the discussion from abstract concepts to concrete experiences and bridges the discussion with additional perspectives. In this way, she uses narrative to encourage reflection, connect the material to relevant personal experiences, and help students understand the social and political climate of the time.

The data indicate that Theresa is sensitive to the feelings of students concerning lines such as "the Captain. . that used the savage that was his guide as a shield", and the atrocities and abuse perpetrated on Native peoples in the Americas. She uses historical information and terminology such as "Noble Savage" to contrast mis-perceptions of Indians and students' personal awareness of cultural values and ethics. Finally, she says John Smith was a very biased writer who "made himself look confident...[but] was wrong". Theresa concludes the class discussion by saying, "Does anyone think John Smith was not wrong? Because I can argue either way; he was a product of his times".

\section{Discussion}

Theresa Morrow's style of teaching combines storytelling and narrative with class content to prepare students for advanced work in critical thinking and to discuss their feelings. She integrates multiple representations of content, encourages perspective-taking, and uses a variety of instructional strategies to insure that students are comprehending the material. As Shor (1992) indicates, her classroom is the context for critical dialogue of the material, and students are encouraged to go beneath the surface of the text to understand 


\section{Table 2}

The teacher uses multiple teaching strategies to encourage students to think critically, discuss ethics and values and reflect on their personal perspectives

"John Smith" narrative
1. Some writers are very biased. John Smith
was biased toward himself and against Indians...
2. England was brutal to the punishment of
criminals, a child 8 years old would be punished
as an adult for stealing a bun to eat. Ironic
because they were savage and brutal...
3. [A] family member had to bring you food if you
wanted to eat

4. Is it wrong to steal food if your children are starving?...

5. They were going to beat [the Puritans] for their beliefs, yet, they left England and continued to do the same things

6. This guy [John Smith] didn't think much of Indian people, yet, they helped him...

7. How did Smith dress? Cloth, cotton, ruffles, tights, boots. How did he see the Native Americans? Breechcloths, animal skins, moccasins, furs, tails, feathers, and painted faces

8. Think about the culture shock! They dressed so differently - seemed not as progressive

9. Do people that dress differently make you feel uncomfortable?

10. Traditional Muslims-women stay behind their husbands - doesn't it set them apart from you? Not in a negative sense [but] will you make comparisons with yourself?...

11. One cannot forget the cultural background that John Smith came from and how unprepared he was for what he found...

12. Colonists saw the opposite of what they were taught — not the "Noble Savage" that they heard about in England

13. Loud Indian parties - seemed like gluttony which was one of the seven deadly sins

$\begin{array}{lll}\text { Synthesis of discussion } \quad \text { Ethics and values } & \text { Teaching strategy }\end{array}$

Discusses bias and Puritan Direct instruction

students' awareness

Defines terms

$\begin{array}{lll}\text { Discusses Puritan } & \text { English } & \text { Inductive reasoning } \\ \text { history. Gives } & \text { Puritan } & \text { Perspective-taking }\end{array}$

examples

Draws comparison American Indian

\begin{tabular}{|c|c|c|}
\hline $\begin{array}{l}\text { Asks critical } \\
\text { questions, students } \\
\text { reflect on } \\
\text { perspectives and } \\
\text { values }\end{array}$ & Students' & $\begin{array}{l}\text { Guided discovery } \\
\text { Perspective-taking }\end{array}$ \\
\hline $\begin{array}{l}\text { Injustice } \\
\text { perpetuating } \\
\text { injustice }\end{array}$ & Puritan & Inductive reasoning \\
\hline $\begin{array}{l}\text { Incongruities. } \\
\text { Negative } \\
\text { perceptions/Indian } \\
\text { generosity }\end{array}$ & $\begin{array}{l}\text { Puritan } \\
\text { American Indian }\end{array}$ & $\begin{array}{l}\text { Multiple } \\
\text { representations of } \\
\text { content }\end{array}$ \\
\hline $\begin{array}{l}\text { Examines difference } \\
\text { in perceptions based } \\
\text { on appearance } \\
\text { Multiple questions } \\
\text { entering encourage }\end{array}$ & $\begin{array}{l}\text { Puritan } \\
\text { American Indian }\end{array}$ & $\begin{array}{l}\text { Critical } \\
\text { consciousness } \\
\text { Critical literacy } \\
\text { Perspective-taking } \\
\text { Deductive reasoning }\end{array}$ \\
\hline
\end{tabular}

Relates to students' Students' Problem-posing personal experiences. Asks questions

Social negotiation

Ties to historical reference. Asks, "Are

Puritan

Critical literacy things always the way they seem?"

Problem-posing

$\begin{array}{lll}\begin{array}{l}\text { States Puritan } \\ \text { philosophy }\end{array} & \text { Puritan } & \begin{array}{l}\text { multiple } \\ \text { representation of } \\ \text { content }\end{array} \\ \begin{array}{l}\text { Asks students to } \\ \text { reflect }\end{array} & \text { Students' } & \end{array}$


Table 2. Continued

\begin{tabular}{|c|c|c|c|}
\hline "John Smith" narrative & Synthesis of discussion & Ethics and values & Teaching strategy \\
\hline $\begin{array}{l}\text { 14. But think about it. There were lots of tribes on } \\
\text { the move - eating when you could - no } \\
\text { preservatives. So eat it while it's there... }\end{array}$ & $\begin{array}{l}\text { Relates to Indian } \\
\text { experiences }\end{array}$ & American Indian & $\begin{array}{l}\text { Critical literacy } \\
\text { Characterizations }\end{array}$ \\
\hline $\begin{array}{l}\text { 15. When you don't understand something most } \\
\text { peoples' reaction is fear, or shock, or terror, or } \\
\text { they make fun of it... }\end{array}$ & $\begin{array}{l}\text { Comments on } \\
\text { actions } \\
\text { Teacher infers } \\
\text { opinion }\end{array}$ & Social & $\begin{array}{l}\text { Complex learning } \\
\text { environment }\end{array}$ \\
\hline $\begin{array}{l}\text { 16. My discussion is focused on helping you deal } \\
\text { with his response }\end{array}$ & $\begin{array}{l}\text { Self-discloses and } \\
\text { states opinion }\end{array}$ & Personal & Draws conclusions \\
\hline $\begin{array}{l}\text { 17. He was from a different place and did not try } \\
\text { to be objective }\end{array}$ & & & $\begin{array}{l}\text { Critical } \\
\text { consciousness }\end{array}$ \\
\hline
\end{tabular}

ideology, social and historical context, and personal consequences. She uses teaching strategies such as direct instruction, multiple representations of content, perspective-taking, and inductive and deductive reasoning to examine ethics and values. Puritan and American Indian contexts are juxtaposed with the teacher's and students' perspectives to provide a wide range of thought provoking discussion and interaction in the class.

Although Theresa Morrow perceives her teaching as "primarily Western in nature" and supportive of individual achievement, the data suggest she uses culturally appropriate strategies to support interdependent development within the classroom. For example, storytelling is an important part of social interaction in this Lakota community, and this congruence is reflected in the literature classes. In addition, narratives are a way of sharing her viewpoints, perspectives, and personal challenges. They are a structure for organizing knowledge and a vehicle of education (Bruner, 1996). Similar to findings of Clandinin and Connelly (1990), and Dyson and Genishi (1994), the teacher's stories provide insights into her world and support the construction of a classroom community that is based on the sharing of information and knowledge. Fig. 1 presents a model of the discussion features and patterns Ms. Morrow uses to juxtapose abstract concepts with concrete experience in the "John Smith" narrative.
As can be seen in Fig. 1, the teacher's stories illustrate and compare multiple contexts, and are a vehicle to discussion that helps students draw comparisons to their experiences. The teacher's self-disclosure provides a personalization of the content and is a way of initiating discussion designed to encourage student understanding. Similar to findings reported by Downs, Javidi, and Nussbaum (1988), the teacher's use of self-disclosure was primarily for clarifying course material, emphasizing content, and helping students organize their thoughts and perceptions. This is a significant aspect of her teaching style that provides students with an awareness of their teacher's feelings and cognitive processes. As Witherall (1991) notes, teaching through narratives "has to do with the power of story and metaphor in offering up possibilities for human action and feeling...The teller or receiver of stories can discover connections between self and other, penetrate barriers to understanding, and come to know more deeply the meanings of his or her own historical and cultural narrative" (p. 94). The stories are told to introduce ideas and concepts, help students interpret course content, and draw connections to their life experiences. These aspects contextualize meaning and reinforce understanding.

The teacher displays professional knowledge and awareness of her own thinking, aspects argued to be those of an expert teacher (Woolfolk, 1998). Her 


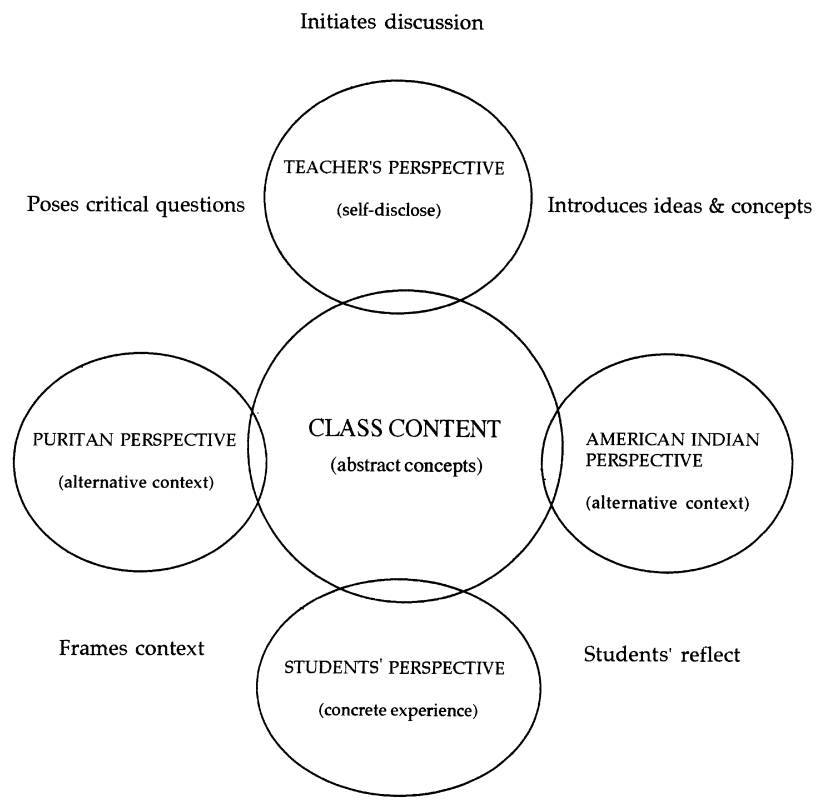

Fig. 1. The narrative model the teacher uses to pose critical questions, introduce ideas and concepts, frame multiple contexts, and encourage students to reflect by contrasting abstract concepts with concrete experiences.

lessons include: (1) an emphasis on understanding; (2) the development of conceptual schemes, interrelated concepts, and global relationships; (3) an awareness of general teaching strategies such as classroom management and evaluation; (4) subject-specific knowledge that she continues to enrich; and (5) an understanding of the characteristics and cultural background of the learners (Lancy, 1993). Similar to findings of Erickson and Mohatt (1982) regarding Odawa teachers, the teacher intuitively found ways of accommodating community principles into her teaching. Discussions of everyday life such as work, personal knowledge, and experience provided students with the opportunity for social interaction, sharing of opinions, and the development of a classroom community. This supported and accommodated community principles.

Another significant aspect of this classroom is the way the teacher communicates her expectations. The teacher lets students know that she has positive expectations of students when she tells them, "I wouldn't expect the same of you", implying an awareness of the difference in amount of experience based on age as opposed to ability. She communicates her learning expectations through her own example and by telling them she hopes they will "get motivated" and go to the library. This statement reflects a Lakota way of encouraging someone to do something without specifically making an assignment or indicating any one particular student. Individuals are given the opportunity to make their own decision, and the teacher's actions provide an example of the appropriate action. As Scollon and Scollon (1981) argue, knowledge is passed on to the learner in a way that demonstrates relevance, yet "minimizes the threat to individual autonomy" (p. 105). The teacher also communicates her expectations implicitly by expecting students to think about the class content, have opinions, and reflect on questions for discussion.

\section{Implications and educational significance}

An underlying premise of this study is the culture of the classroom community. The community 
shapes the school experience for and with students, and supports the notion that "learning as a phenomena occurs in relation to other factors" (Weade, 1998, p. 88). In schools, "education cannot be treated as an institution separate from communities" (Saravia-Shore, 1992, p. 73); it must be an integral part of the curricula based on the community it serves. Furthermore, "the process of exchange and negotiation - this culture creating - is a feature of classroom[s]", and it is based on "an exercise in collectivity, one that depends upon the attunement of the teacher to the expressions and intents" (Bruner, 1986, p. 132) of the students and vice versa. Helping teachers to identify and support this perspective necessitates looking at the contexts of teachers' work and the strategies effective teachers use. In order to connect teachers' work with students, there must be an understanding of differences that arise from culture, language, family and community (Darling-Hammond, 1997). By increasing teacher knowledge and understanding of ethnic and cultural perspectives, this may be possible. As Heath (1986) notes, "academic success depends not on the qualifications or the specific language children know, but on the ways of using language that they know" (p. 84).

Fig. 1 presents an important model for teachers in American Indian communities and in contexts where interdependent development is the primary means of social interaction. Classrooms that support this interdependent focus need to be acknowledged and valued as significant for teaching and learning both content and process. More importantly, it presents a model for all classrooms and supports the notion that "many teachers have found new ways to function interdependently in complex systems" (Weade, 1998, p. 96). This model based on the teacher's use of narrative to juxtapose abstract concepts and concrete experiences, encourage perspective taking, and provide multiple representations of content is a meaningful way of combining cognitive and affective learning into class discussions. Narratives are a way to understand communities and contexts as "cultural resources that serve such purposes as selfidentification, self-criticism, and social solidification" (Gergen, 1994, p. 188). As Witherall (1996) notes, the opportunity for "imagining the experi- ence and feelings of others [through] story and metaphor provide a form of educational encounter that renders us human and frees the moral imagination" (Witherall, 1991, p. 94).

Although these are the stories of only one teacher, they provide a striking example of how this teacher uses narrative to help students understand content, share feelings, and convey the material in a culturally significant way. The teacher's stories are avenues to the social construction of a classroom community "accomplished through the everyday actions" of teachers and students acting together (Santa Barbara Discourse Group, 1998). As McLaren and Lanksher (1993) remind us, students need the opportunity to explore different perspectives "for rethinking the relationship of self and society, self and other, and for deepening the moral vision of society" (p. 424). The teacher in this study provides students with this opportunity in her lectures and in class discussions by utilizing narratives for portraying relationships and multiple perspectives. Narrative supports the organization and structure of relationships, and is "the mode of thinking and feeling that helps children (indeed people generally) create a version of the world in which, psychologically they can envisage a place for themselves - a personal world" (Bruner, 1996, p. 39).

Further research is needed, however, into the importance of narrative for constructing supportive relationships with students and its relevance in supporting and assessing student learning. If we are to be able to address the issue of teacher authority versus the empowerment of students, we must be willing to continually seek new ways of fostering collaboration and interdependence in classrooms. We must seek out means that not only engage students in individual work, but also encourage cooperation, foster multiple perspectives, and create classroom communities that can work effectively together.

\section{Acknowledgements}

The author would like to express grateful appreciation to the teacher and students who permitted access to their classes, ideas, and discussions. I hope the ideas presented will prove useful to 
teachers and others as they attempt to find ways to help all students succeed.

\section{References}

Banks, J. A. (1993). The canon debate, knowledge construction, and multicultural education. Educational Researcher, 22(5), 4-14.

Berg, B. L. (1998). Qualitative research methods for the social sciences. Boston, MA: Allyn and Bacon.

Braid, D. (1996). Personal narrative and experiential learning. Journal of American Folklore, 109(431), 5-30.

Bruner, J. S. (1986). Actual minds, possible worlds. Cambridge, MA: Harvard University.

Bruner, J. (1991). The narrative construction of reality. Critical Inquiry, 21.

Bruner, J. S. (1996). The culture of education. Cambridge, MA: Harvard University Press.

Cajete, G. (1994). Look to the mountain: An ecology of Indigenous education. Durango, CO: Kivaki Press.

Chafe, W. (1990). Some things that narrative tell us about mind. In B. K. Pellagrini, \& A. D. Britton, Narrative thought and narrative language (pp. 79-98). Hillsdale, NY: Lawrence Erlbaum Assoc. Publications.

Clandinin, D. J., \& Connelly, F. M. (1990). Narrative and story in practice and research. In D. Schön, The reflective turn: Case studies of reflective practice (pp. 258-282). New York: Teachers College Press.

Cole, M. (1996). Cultural psychology: The once and future discipline. Cambridge, MA: The Belknap Press of Harvard University Press.

Cole, M., John-Steiner, V., Scribner, S., \& Souberman, E. (1978). L. S. Vygotsky mind in society: The development of higher psychological processes. Cambridge, MA: Harvard University Press.

Collinson, V. (1993). Teacher's as learners: Exemplary teacher's perceptions of personal and professional renewal. Unpublished dissertation, Ohio State University.

Cook-Gumperz, J. (1986). The social construction of literacy. New York: Cambridge University Press.

Darling-Hammond, L. (1997). The right to learn: A blueprint for schools that work. San Francisco: Jossey-Bass Inc.

Dauenhauer, N., \& Dauenhauer, B. (1990). Haa Tuwuna'agu Yi's: For healing our spirit. Seattle, WA: University of Washington Press.

Delgado-Gaitán, C., \& Trueba, H. (1991). Crossing cultural borders: Education for immigrant families in America. Bristol, PA: Falmer Press.

Downs, V. C., Javidi, M., \& Nussbaum, J. F. (1988). An analysis of teacher's verbal communication within the college classroom: Use of humor, self-disclosure, and narrative. Communication Education, 37, 127-141.

Dyson, A. H., \& Genishi, C. (1994). The need for story: Cultural diversity in classroom and community. Urbana, IL: National Council of Teachers of English.
Eckermann, A. K. (1994). One classroom, many cultures. St. Leonards, NSW: Allen and Unwin.

Egan, K. (1987). Literacy and the oral foundations of education. Harvard Educational Review, 57(4), 445-472.

Erickson, F., \& Mohatt, G. (1982). Cultural organization of participation structures in two classrooms of Indian students. In G. Spindler, Doing the ethnography of schooling: educational anthropology in action (pp. 132-174). New York: Holt, Reinhart and Winston.

Freire, P. (1970/1996). Pedagogy of the oppressed. NY: Continuum Pub.

Gallimore, R., \& Tharp, R. (1990). Teaching mind in society: Teaching schooling and literate discourse. In L. Moll, Vygotsky and education: Instructional implications and applications of sociohistorical psychology (pp. 175-205). New York: Cambridge University Press.

Gergen, K. J. (1994). Realities and relationships: Soundings in social relationships. Cambridge: Harvard University Press.

Glaser, B., \& Strauss, A. (1967). The discovery of grounded theory: Strategies for qualitative research. Chicago: Aldine Pub. Co..

Greenfield, P., \& Cocking, R. (1994). Cross cultural roots of minority child development. Hillsdale, NJ: Lawrence Erlbaum Associates Inc.

Goody, J. (1987). The interface between the written and the oral. New York: Cambridge University Press.

Havelock, E. A. (1986). The muse learns to write. New Haven, NY: Yale University Press.

Heath, S. B. (1982). Ethnography in education: Defining the essentials. In P. Gilmore, \& A. A. Glatthorn, Children in and out of schools: Ethnography and education. Washington, DC: Center for Applied Linguistics.

Heath, S. (1986). Taking a cross-cultural look at narratives. Topics in Language Disorders, 7, 84-94.

Holladay, S. J. (1984). The functional impact of narrative activity in effective teaching. Unpublished masters thesis, Purdue University.

Hymes, D. H. (1981). In vain I tried to tell you. Philadelphia: University of Pennsylvania.

Joe, J. (1994). Revaluing Native American concepts of development and education. In P. Greenfield, \& R. Cocking, Cross cultural roots of minority child development (pp. 107-113). Hillsdale, NJ: Lawrence Erlbaum Associates Inc.

John-Steiner, V., Panofsky, C. P., \& Smith, L. (1994). Sociocultural approaches to language and literacy. New York: Cambridge University.

John-Steiner, V., \& Souberman, E. (1978). Afterward. In M. Cole, V. John-Steiner, S. Scribner, \& E. Souberman, L. S. Vygotsky mind in society: The development of higher psychological processes (pp. 121-134). Cambridge, MA: Harvard University Press.

Lancy, D. F. (1993). Qualitative research in education. an introduction to the major traditions. White Plaines, NY: Longman Publishing Group.

McAlpine, L., Eriks-Brophy, A., \& Crago, A. (1996). Teaching beliefs in Mohawk classrooms: Issues of language and culture. Anthropology and Education Quarterly, 27(3), 390-413. 
McLaren, P. (1995). White terror and oppositional agency: Towards a critical multiculturalism. In P. McLaren, R. Hammer, D. Sholle, \& S. S. Reilly, Rethinking media literacy: A critical pedagogy (pp. 87-124). New York: Peter Lang Pub..

McLaren, P., \& Lanksher, C. (1993). Critical literacy and the postmodern turn. In C. Lankshear, \& P. L. McLaren, Critical literacy, politics, praxis and the postmodern (pp. 421-426). Albany: State University of New York Press.

Miles, M. B., \& Huberman, A. M. (1994). Qualitative data analysis: An expanded sourcebook. Thousand Oaks, CA: Sage Publications.

Moll, L. (1990). Vygotsky and education: Instructional implications and applications of sociohistorical psychology. New York: Cambridge University Press.

Nieto, S. (1996). Affirming diversity: The sociopolitical context of multicultural education. White Plains, NY: Longman Publishers.

Ong, W. J. (1982). Orality and literacy: The technologizing of the word. New York: Routledge.

Patton, M. Q. (1990). Qualitative evaluation and research methods. Newbury Park, CA: Sage Publications.

Philips, S. U. (1983). The invisible culture: Communication in classroom and community on the Warm Springs Indian Reservation. New York: Longman, Inc.

Santa Barbara Discourse Group (1998). Constructing literacy in classrooms: Literate action as social accomplishment. In
H. H. Marshall, Redefining student learning (pp. 119-151). Norwood, NJ: Ablex Publishing Corp.

Saravia-Shore, M. (1992). Cross-cultural literacy: Ethnographies of communication in multiethnic classrooms. Berkeley, CA: Stanford University Press.

Scollon, R., \& Scollon, S. (1981). Narrative, literacy and face in interethnic communication. Norwood, NJ: Ablex Pub. Corp.

Shor, I. (1992). Empowering education: Critical teaching for social change. Chicago, IL: University of Chicago Press.

Stake, R. E. (1995). The art of case study research. Thousand Oaks, CA: Sage.

Swann, B. (1994). Coming to light: Contemporary translation of the Native literature of North America. New York: Random House Inc.

Tharp, R., \& Gallimore, R. (1988). Rousing minds to life: Teaching, learning and schooling in social context. New York: University of Cambridge.

Weade, G. (1998). Locating learning in the times and spaces of teaching. In H. H. Marshall, Redefining student learning (pp. 87-118). Norwood, NJ: Ablex Publishing Corp.

Witherall, N., \& Noddings, N. (1991). Stories lives tell: Narrative and dialogue in education. New York: Teachers College Press.

Woolfolk, A. (1998). Educational psychology. Boston, MA: Allyn and Bacon.

Yin, R. K. (1994). Case study research: Design and methods. Thousand Oaks, CA: Sage Publications. 